\title{
Expanding entrepreneurship opportunities through local governance: the case of Barbados
}

\author{
Commonwealth Journal of Local Governance \\ Issue 16/17: June 2015 \\ http://epress.lib.uts.edu.au/ojs/index.php/cjlg
}

\author{
Paul Pounder \\ Department of Management Studies \\ Cave Hill Campus \\ The University of the West Indies \\ Barbados
}

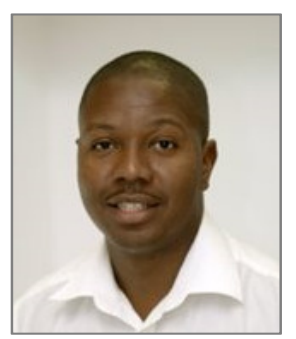

\begin{abstract}
This paper looks at the government and local governance structures of Barbados, arguing that local governance should be leveraged to expand entrepreneurship opportunities at the community level. It examines the links between local governance and entrepreneurship, and proposes a framework aimed at strengthening the relationship between Barbados' newly formed constituency councils and its government institutions supporting entrepreneurship. The research concludes that there are many inefficiencies in the interaction between government agencies and constituency councils, which the proposed framework is a first step toward remedying. The research suggests that local governance is a complex issue worldwide. More specifically in Barbados, even though the role of the constituency councils is defined, there are weak formal arrangements which undermine the processes and activities to support community entrepreneurship. The proposed framework highlighted in the research is a first step in formalising a way forward for entrepreneurship in the community.
\end{abstract}

Key words: local governance, entrepreneurship, decentralisation, policy framework, Barbados

\section{Introduction}

The Caribbean is a group of countries nestled between North and South America, with each country having its own distinct history and evolution over the past 300 years. Barbados, the most easterly of these Caribbean islands, was in many respects England's first experimental export colony, with trade taking place between the sugar plantations and the processing plants in England (Watson 2011). The country has come a long way: from a mono-crop sugar-cane economy governed as a British colony from the $16^{\text {th }}$ to the $20^{\text {th }}$ century, to a democracy where entrepreneurship is prevalent in many areas of operation.

(C) 2015 Paul Pounder. This is an Open Access article distributed under the terms of the Creative Commons Attribution 4.0 Unported (CC BY 4.0) License (https://creativecommons.org/licenses/by/4.0/), allowing third parties to copy and redistribute the material in any medium or format and to remix, transform, and build upon the material for any purpose, even commercially, provided the original work is properly cited and states its license. 
The model used for Barbados' governing authority, referred to as the parliament, emerged out of a Commonwealth framework. The parliament comprises an elected House of Assembly which has 30 members elected on a five-year electoral cycle. The winner of the election is called the prime minister and this elected individual rules the country through the delegation of duties to other party members who oversee various critical ministries (eg Ministry of Agriculture, Ministry of Commerce and Ministry of Health). There is also an appointed senate, which has 21 members appointed by the governor-general: 12 on the advice of the prime minister, two on the advice of the leader of the opposition and the remaining seven at the governor-general's discretion.

Although Barbados is a parliamentary democracy with an elected government, but there is no elected local governance system. However, the Constituency Council Act 2009 created a new Department of Constituency Empowerment within the Ministry of Social Care, Constituency Empowerment and Community Development. This department is tasked with overseeing the creation and activities of newly formed 'constituency councils' within Barbados' 30 constituencies. The councils are designed to be representative of, and for, each constituency on the island. The members of the council are nominated (not elected), to represent one of the following: a community group, a special interest group, a political organisation represented in the national parliament, or the minister responsible for constituency councils (Constituency Councils of Barbados).

The country's current trends in public policy demonstrate interest in the possibility of expanding entrepreneurship opportunities at community level. However, the policies are broad rather than specific, leaving a need for a framework that spurs an entrepreneurial ecosystem. Although the main role of a constituency council is to act as intermediary between agencies of government and the community for information and the delivery of social and other services, aspiring community entrepreneurs still find it difficult to start a new venture. The current paper explores how entrepreneurship opportunities can be expanded through the use of local governance as a mechanism for reaching government agencies and interpreting and implementing policy.

\section{Methods}

This paper represents exploratory research. The overall objective of the research study is to provide insight into local governance as identified by accessible literature. The research focused on reviewing the academic literature on governance and entrepreneurship. The research considers entrepreneurship progress through local governance. Further, the research develops a perceptive way to highlight how the existing local governance framework in Barbados could be leveraged to support entrepreneurship through existing initiatives. Limitations of the study were highlighted. 


\section{Local governance}

\section{Defining local governance}

Recent research suggests that the role and social prestige of political parties, which constitute local government run by state institutions and elected representatives, has decreased significantly and is gradually being replaced by a new form of decision-making referred to as local governance (eg Rhodes 1996; Andrew and Goldsmith 1998; Hoffmann-Martinot 1998; Stoker 1998; John 2001). Rhodes (1996: 652-653) refers to governance as a 'new process of governing; or a changed condition of ordered rule; or the new method by which society is governed'; he further defines governance as 'self-organizing, interorganizational networks, which complement markets and hierarchies as governing structures for authoritatively allocating resources and exercising control and co-ordination'. Therefore, whereas local government was once seen as the sole co-ordinator of local services and activities, the evolution from government to governance is making politicians and local authorities 'increasingly more oriented to policy outcomes and adequate service provision' (Haus and Sweeting 2006). In turn, this means they are actively engaging the participation and involvement of actors from public, private and voluntary sectors to form exchange networks which are aimed at collectively negotiating national policy for the country, while decentralising government activities to a cross-section of external agents (Andrew and Goldsmith 1998; John 2001; Carley 2006; Alba and Navarro 2006).

\section{Local governance and decentralisation}

Osborne (1993) suggests that decentralisation is an indication of empowerment, pushing decisions from one level to another. Treisman (2002: 5-13) identified six types of decentralisation, which he outlines and defines as:

1. Vertical decentralisation - refers to the number of tiers a system contains.

2. Decision-making decentralisation - focuses on how authority to make political decisions is distributed among different tiers.

3. Appointment decentralisation - is concerned with the level at which officials at different tiers are selected and dismissed.

4. Electoral decentralisation - looks at the proportion of tiers at which direct elections are held to pick executives (or to pick legislators who then choose an executive from their number).

5. Fiscal decentralisation - is concerned with the way tax revenues and public expenditures are distributed among the different tiers.

6. Personnel decentralisation - focuses on how administrative resources are distributed across tiers of government. 
His study concluded that: 'Countries with large populations tend to have greater vertical, decisionmaking, fiscal and personnel decentralisation, but they are not more likely to have local electoral accountability or local selection of officials. Countries in which ethnolinguistic minorities make up a large share of the population tend to have more tiers of government - but less decentralization of fiscal resources and administrative personnel and less local electoral accountability. More democratic countries tend to have fewer tiers of subnational government at which leaders are appointed rather than elected.' (Treisman 2002: 35)

Faguet (2014) conducted a study which focused on the role decentralisation plays in 'deepening democracy and improving governance', where he highlighted a number of nations across the world (eg Argentina, Bolivia, Britain, Cambodia, Egypt, Peru) where the governments, in Faguet's summation, implemented decentralisation strategies in an attempt to 'reconstitute government - from a hierarchical, bureaucratic mechanism of top-down management to a system of nested self-governments characterised by participation and cooperation, where transparency is high and accountability to the governed acts as a binding constraint on public servants' behaviour'. (p. 2)

Faguet's study concluded that decentralisation can increase political competition by offering new avenues of entry for budding politicians, while also reducing political instability and limiting the special privileges granted to powerful elites, thus threatening elite access to the 'democratic game' Faguet (2014).

It is true that much of the research on and evidence for the transformation of 'local government' to 'local governance', alongside the development and implementation of decentralisation policies and strategies, comes from areas such as western Europe, the Nordic countries and the US. However, in Barbados a case has been made by the ruling Democratic Labour Party for the decentralisation of powers. The thinking is that such decentralisation is a pre-requisite of a more democratic society. For the purpose of this research paper, democratic decentralisation is defined as the transfer of resources and power (and often of tasks) to lower-level authorities which are largely or wholly independent of higher levels of government and which are democratic in some way and to some degree (Manor 1999: 6-7). Local governance through constituency councils entails the decentralisation of powers such that the national government may operate with sufficient authority and resources to bring about economic development and social justice. Research has shown that there is growing interest in new forms of 'distributed local governance that draws on the skills and resources of public, private, and civil society sectors' (Reddel and Woolcock 2004: 81). Local governance is also known to play a significant part in grassroots-level development, by responding to critical local needs. It is recognised as a cornerstone in making elected Central government representatives familiar with the problems of the local community, especially as they relate to poverty alleviation. 
Thus local governance, also referred to as 'network', 'citizen-centred' or 'community' governance, is effective where local authorities see their role as a first among equals; an arrangement which frequently arises in local-authority-led partnerships where, through decentralisation, the public are considered to be co-producers of services and innovation (Clarke and Stewart 1994; Stewart 1995; Hartley 2005; Lee, Hwang and Choi 2012). Such new-found collaborative arrangements encourage innovation through the integration of government and external parties, allowing all actors to access a network of expert players who can potentially solve problems faster and more efficiently (Albury 2005; Arganoff 2007; Nambisan 2008; Lee, Hwang and Choi 2012).

\section{Functions, benefits and constraints of local governance}

Over the years, a number of theorists and practitioners have explored the concept of governance, outlining the functions, benefits and limitations of this new form of ruling (eg Oakerson and Parks 1989; Haque 1997; Blair 2000; Denters and Rose 2005; Stoker 2011; Krott, Bader, Schusser, Devkota, Maryudi, Giessen and Aurenhammer 2014; Evans and O'Brien 2015). Haque (1997) explored the nature of locallevel accountability in local governance, suggesting that local governance is essential to socio-economic activity in developing countries, because it addresses local needs no longer addressed by the state. However, he also highlighted a number of social, economic, political and administrative constraints (eg imbalances in the power structure, the dominance of bureaucracy) which could hinder socio-economic development.

According to Stoker (2011), at the beginning of the $21^{\text {st }}$ century the core functions of local governance were to support political identity and economic development (social investment), to facilitate social welfare provision (social consumption) and improved quality of life. However, Stoker also reflected on significant limitations to the role of governance that he and his counterpart Rhodes had overlooked in previous studies (eg Rhodes 1989, 1997; Stoker 2004, 2005) - such as not recognising the significance of power, and the lack of support for a societal role for government. Evans and O'Brien (2014) discussed the concept of 'soft infrastructure for sustainable development', concluding that 'the more effective the governance process, the more effective the development of capacity and the more resilient and sustainable society' (p. 93). 'Soft infrastructure' such as participatory processes may thus have a positive impact on economic development, given the evidence that there are environmental limits to economic growth.

With respect to Barbados, tourism, international business, agriculture and renewable energy have all been promoted as economic development priorities in its various development documents (eg the MediumTerm Development Strategy 2010-2014 and the National Strategic Plan of Barbados 2005-2025) - all of 
which can spur entrepreneurship. It is therefore envisaged that local governance will spearhead plans and initiatives at constituency level to boost economic activity and local wealth creation within the parishes.

\section{Link between local governance and entrepreneurship}

Local governance has been seen as encouraging the sustainable growth of local small businesses, through the processes of decentralisation that occur in developing economies. Local institutions can stimulate entrepreneurship by creating an environment that aids skills development of entrepreneurs and lowering the barriers to start-up. It is also the case that economic development at micro level is significant for improving quality of life. This indicates that initiatives supporting entrepreneurship should be encouraged at the local governance level. Due to financial fluctuations and the speed of change of consumer trends, there exists a significant relationship between local entrepreneurship and local development (Arzeni \& Pellegrin 1997).

\section{Entrepreneurship as an economic stimulus}

As previously mentioned, the role of entrepreneurship as an economic stimulus has received much recent attention from academics and policymakers (eg Thompson \& Rushing 1999; Cooke 2001; Acs \& Szerb 2007; Thurik 2009; Samila and Sorenson 2011). The stimulation of entrepreneurial activity has the potential to contribute positively to a country's economy (Rocha 2004; Acs \& Szerb 2007). Yet, despite this positive relationship between entrepreneurship and economic growth, entrepreneurs are still forced to manoeuvre around countless pieces of legislation and policy initiatives, all of which impact on their activities in some way. It may be that this is because most policies are geared towards firms, not individual entrepreneurs (Acs 2006), but it should be remembered these make up the majority of entrepreneurs in small-island developing states such as Barbados.

The entrepreneur as an individual is forced to take a number of common-sense steps to address the challenges of the changing environment. Dunning and Narula (1997) and Singh (2001) suggest that developing countries should enhance the ability of their small firms to access and utilise effectively the stock of knowledge available from firms in economically and technologically advanced countries. This could be easily encouraged through local governance initiatives. As suggested by John (2001), businesses recognise that their competitiveness is affected by political issues, and therefore need to engage with policymakers to operate effectively. John's study further suggests that in a volatile and cut-throat environment, holistic solutions to pressing problems can only be found by involving a cross-section of agencies which represent all functions and levels within the regulatory and statutory framework. Similarly Stathopoulou, Psaltopoulos and Skuras (2004: 408) suggest that governance must respond to the notion that 'a firm's activities are not carried out individually but work towards taking up formal and informal 
information networks, relations through local labour markets, and common conferences and rules for developing infrastructure and understanding the processes of knowledge accumulation.' They further submit that this kind of collaboration can 'facilitate entrepreneurship by creating a business environment favouring innovation, assisting entrepreneurship and appeasing locational, environmental and economic obstacles. In contrast, the absence of such forces may restrain entrepreneurship.'

Conversely, Acs (2006) submits that less developed countries should focus on policies which are geared towards General National Framework Conditions, as this focuses on the advancement of established general business activity at the national levels; rather than Entrepreneurial Framework Conditions, as this focuses towards high-growth entrepreneurial activity. It is also suggested that foreign direct investment (FDI) can be beneficial to local economies, as well as policies that encourage FDI; such initiatives can potentially reduce self-employment by individuals whose attempt at entrepreneurial activities may only stunt economic growth rather than spur it on.

All things considered, it is evident that governance is firmly on the policy agenda in developing countries (Stoker 1998), and thus the establishment of a governance policy framework is imperative to the successful economic development of a small island state such as Barbados.

\section{Policy framework}

Agencies, governments and institutions around the world have utilised a variety of policy frameworks to guide them concerning their individual purposes and agendas. Some examples of their scope - the Government of Alberta's Social Policy Framework, the Organisation for Economic Co-operation and Development (OECD)'s Policy Framework for Investment, and the UK Government's National Planning Policy Framework - are cited here.

Alberta's Social Policy Framework aims to: 'have social policies, programs, and systems that produce better results (also known as "outcomes"). These outcomes frame and set the overall purpose and direction of social policy in Alberta. They will provide the government and its partners with an effective tool for focusing social policy priorities and actions for the next 10 to 15 years.' (Government of Alberta, 2013: 10)

The OECD's Policy Framework for Investment 'is a tool, providing a checklist of important policy issues for consideration by any government interested in creating an environment that is attractive to all investors and in enhancing the development benefits of investment to society, especially the poor. In this way, the Framework aims to advance the implementation of the United Nations Monterrey Consensus, 
which emphasised the vital role of private investment in effective development strategies'. (OECD 2006: 7)

The UK's National Planning Policy Framework 'sets out the Government's requirements for the planning system only to the extent that it is relevant, proportionate and necessary to do so. It provides a framework within which local people and their accountable councils can produce their own distinctive local and neighbourhood plans, which reflect the needs and priorities of their communities' (Department for Communities and Local Government, 2012: 1).

These approaches suggest that the establishment of frameworks can help agencies, governments and institutional bodies to develop and evaluate programmes and policies in a proactive and preventative fashion (Government of Alberta 2013). The present paper argues that the establishment and implementation of a policy framework to support entrepreneurship is crucial for Barbados and its economic development, and the collaboration of government and non-government actors from a crosssection of sectors and industries, through local governance processes, will be integral to the success of such an undertaking.

\section{Institutional and policy framework in Barbados}

For the past twenty years, the Barbados Government has invested in a plethora of initiatives aimed at supporting and growing the small business and entrepreneurial sector. However Barbados' entrepreneurial policy, though purposeful, is not focused; it takes a general approach which supports the national strategy on the development and promotion of enterprises in Barbados. The present research speaks to the need for the government to create focused measures for small businesses: an enabling legal framework; access to pertinent information and advice; better access to equipment and other input procurements; and enhanced access to finance and affordable physical infrastructure.

The creation of an entrepreneurial environment has been a vision of many practitioners, policymakers and government officials in Barbados. Public sector support for entrepreneurial development is based on a number of core objectives, and awareness of these objectives is critical for the development of effective policy support. The following are viewed as fundamental goals of entrepreneurial support:

- creation of sustainable jobs

- stimulation of the competitiveness of the economy

- increased contribution to economic growth

- higher levels of domestic and foreign investment as well as exports 
The objectives of the entrepreneurial policy support need to find practical expression in the local governance framework. (Rocha 2004; Acs 2006; Acs \& Szerb 2007)

\section{Findings}

\section{Summary of policy developments for the entrepreneurial sector}

Barbados policymakers have tended to rely too heavily on a favourable tax regime to stimulate and attract entrepreneurs. However, relying exclusively on a favourable business climate (as measured by taxes, regulations and legislative incentives) fails to address the essential needs of entrepreneurs.

Barbados offers diverse attractions for regional and international tourists including a unique weather pattern and miles of beaches. Opportunities exist for investment in resort hotels, business and tourist hotels, and high-end hotels. Opportunities also exist for healthcare services at all levels. However, local governance structures do not facilitate the conversion of these opportunities.

Table 1 highlights some key entrepreneurship initiatives, all introduced prior to the Constituency Council Act 2009. The onus is therefore on constituency councils to design a framework that harnesses each of these initiatives. This paper proposes the adoption of a national policy framework that establishes guidelines to facilitate entrepreneurship and empowers potential entrepreneurs.

Table 1: Local Government Entrepreneurship Initiatives

\begin{tabular}{|l|l|l|}
\hline Year & Institution & Programme Activities Offered \\
\hline 1995 & $\begin{array}{l}\text { Small Business Development Unit (SBDU) within } \\
\text { the then Ministry of Commerce, Consumer Affairs, } \\
\text { and Business Development }\end{array}$ & Research and policy development \\
\hline 1995 & Youth Entrepreneurship Scheme (YES) & Technical assistance to youth enterprises \\
\hline 1998 & Enterprise Growth Fund Limited (EGFL) & $\begin{array}{l}\text { Loans from dedicated sector-specific funds (eg } \\
\text { agriculture, industry, tourism) }\end{array}$ \\
\hline 1998 & $\begin{array}{l}\text { Barbados Agency for Microenterprise } \\
\text { Development (Fund Access) }\end{array}$ & $\begin{array}{l}\text { Small loans (up to US\$50,000), technical } \\
\text { assistance and enterprise training }\end{array}$ \\
\hline 1998 & $\begin{array}{l}\text { Barbados Small Business Development Centre } \\
\text { within the Barbados Investment and Development } \\
\text { Corporation (BIDC) }\end{array}$ & $\begin{array}{l}\text { Business development services, secretariat } \\
\text { services, technical assistance, mentorship and } \\
\text { innovation support }\end{array}$ \\
\hline 1999 & $\begin{array}{l}\text { SBDU - under the Small Business Development } \\
\text { Act (SBDA) }\end{array}$ & $\begin{array}{l}\text { Creation of a regulatory framework and } \\
\text { provision of tax incentives }\end{array}$ \\
\hline $2000 / 01$ & $\begin{array}{l}\text { Enterprise Units at the Urban Development } \\
\text { Corporations }\end{array}$ & $\begin{array}{l}\text { Technical assistance and small loans and } \\
\text { grants }\end{array}$ \\
\hline $2000 / 01$ & $\begin{array}{l}\text { Enterprise Units at the Rural Development } \\
\text { Corporations }\end{array}$ & $\begin{array}{l}\text { Technical assistance and small loans and } \\
\text { grants }\end{array}$ \\
\hline 2001 & $\begin{array}{l}\text { BIDC's Special Technical Assistance Programme } \\
\text { (STAP) }\end{array}$ & $\begin{array}{l}\text { Business development services, technical } \\
\text { assistance, small grant funds }\end{array}$ \\
\hline 2003 & $\begin{array}{l}\text { EGFL's Innovation Fund } \\
\text { Eoans for research and development and } \\
\text { prototyping }\end{array}$ \\
\hline 2007 & $\begin{array}{l}\text { Entrepreneurial Development Division (EDD) - a } \\
\text { rebrand of SBNED (Small Business and New } \\
\text { Enterprise Division) of BIDC }\end{array}$ & $\begin{array}{l}\text { Business development services, secretariat } \\
\text { services, technical assistance, mentorship and } \\
\text { innovation support }\end{array}$ \\
\hline 2008 & National Microenterprise Programme & Technical assistance and small loans \& grants \\
\hline
\end{tabular}




\section{Proposed framework for community entrepreneurship}

The Government of Barbados needs to develop and enact legislation which will encourage community entrepreneurship by making provision for research, legal and financial support to potential entrepreneurs. It should include new venture development within a review of the Small Business Development Act. Local incubation units ${ }^{1}$ and clusters ${ }^{2}$ should be set up near constituency councils across the island. An incubation unit can be described as a system or facility which supports new businesses at the outset, and helps them to survive and advance during what is a precarious stage in the business development process (Aernoudt 2004). Business clusters can be defined as 'geographic concentrations of interconnected companies and institutions in a particular field' (Porter 1998: 78). The establishment of incubation units and clusters would encourage networking and provide adequate infrastructure for taking enterprises to the next level. ${ }^{3}$ Each incubatee/cluster member would be linked to a business development officer (BDO) with the Entrepreneurial Development Division (EDD) of the Barbados Investment and Development Corporation. The BDO would help potential entrepreneurs not only by providing information, advice and suggestions, but also by linking them with the local and global funding agencies which support new ventures - mainly the Fund Access and Enterprise Growth Fund Ltd. which is company set up by the Barbados Government. Further assistance might be required with writing funding proposals. The Ministry of Social Care, Constituency Empowerment and Community Development would oversee, co-ordinate, monitor and facilitate all activities of the local incubation units and clusters, with the overarching aim of providing all necessary support for their development. These businesses should thus grow and rise to the point of graduating out of the incubator/cluster so that new potential entrepreneurs can join the programme. Rewards and incentives should be provided to entrepreneurs who outperform others and show good performance metrics when assessed on employment, net foreign exchange earnings and greening initiatives.

\section{Conclusion}

Research shows that local governance is a complex issue, including in a small-island developing state like Barbados. In Barbados the framework for local governance is still very much in its infancy and is far from clear-cut. Even though the role of constituency councils is defined, they are still in the infancy stage of operation. This means the relationship between constituency councils and those government

\footnotetext{
${ }^{1}$ Incubation units, a term derived from 'business incubators', are being recognised as being one of the most effective ways of promoting entrepreneurial activity and local economic development (Adegbite 2001: 1).

${ }^{2}$ Localised clustering has been identified as having significant relevance to economic development, policy planning, entrepreneurship and innovation (Rosenfeld 1997; Bennett, Graham and Bratton 1999; Clarke 2009).

${ }^{3}$ Wennberg and Lindqvist (2008: 3) found that being in a cluster had a positive impact on new firms, while being near firms that were in the same or related industries was found to be associated with better survival, higher job creation, higher tax payments, and higher salary payments in new firms.
} 
institutions designed to facilitate entrepreneurship are underdeveloped. This paper's proposed framework for community entrepreneurship seeks to address this issue by creating transparent lines of communication and control areas, and it is therefore recommended that the government support this structure.

The proposed framework is a first step in developing a way forward for community entrepreneurship. It is an attempt to remedy some of the existing difficulties in interaction between constituency councils and governmental institutions in Barbados. However, it should be noted that these interactions will vary and thus a case-by-case perspective must be adopted.

\section{Limitations of research}

The research has identified a considerable body of literature on both local governance and entrepreneurship. However there is limited evidence on the relationship between local governance and entrepreneurship, which makes this research exploratory in nature.

\section{References}

Acs, Z. J. 2006. How is entrepreneurship good for economic growth? Innovations 1(1), pp. 97-107. doi: http://dx.doi.org/10.1162/itgg.2006.1.1.97

Acs, Z. J. and Szerb, L. 2007. Entrepreneurship, economic growth and public policy. Small Business Economics 28(2-3), pp. 109-122. doi: http://dx.doi.org/10.1007/s11187-006-9012-3

Adegbite, O. 2001. Business incubators and small enterprise development: the Nigerian experience. Small Business Economics 17(3), pp. 157-166. doi: http://dx.doi.org/10.1023/A:1011801018398

Aernoudt, R. 2004. Incubators: tool for entrepreneurship? Small Business Economics 23(2), pp. 12. doi: http://dx.doi.org/10.1023/B:SBEJ.0000027665.54173.23

Alba, C. R. and Navarro, C. 2006. Mayors and local administrators: a puzzling relationship. In: Bäck, H. et al. eds. The European Mayor: Political Leaders in the Changing Context of Local Democracy. $10^{\text {th }}$ ed. VS Verlag für Sozialwissenschaften, pp. 287-309. doi: http://dx.doi.org/10.1007/978-3-531-90005-6_13

Arzeni, S. and Pellegrin, J-P. 1997. Entrepreneurship and Local Development. OECD Observer, 204 (February/March), pp. 27-29.

Bennett, R. J. et al. 1999. The location and concentration of businesses in Britain: business clusters, business services, market coverage and local economic development. Transactions of the Institute of British Geographers 24(4), pp. 393-420. doi: http://dx.doi.org/10.1111/j.0020-2754.1999.00393.x

Blair, H. 2000. Participation and accountability at the periphery: democratic local governance in six countries. World development 28(1), pp. 21-39. doi: http://dx.doi.org/10.1016/S0305-750X(99)00109-6

Carley, M. 2006. Partnership and statutory local governance in a devolved Scotland. International Journal of Public Sector Management 19(3), pp. 250-260. doi: http://dx.doi.org/10.1108/09513550610658213

Clark, G. 2009. Clusters, Innovation and Entrepreneurship. Paris: OECD.

Constituency Council Act. 2009 [Online] Available at: http://www.barbadosparliament.com/htmlarea/uploaded/File/Act/2009/The\%20Constituency\%20Councils $\% 20$ Act,\%202009.pdf [Accessed: 10 April 2015] 
Constituency Councils of Barbados. 2015. [Online] Available at: http://www.CCs.gov.bb [Accessed: 17 April 2015]

Cooke, P. 2001. Regional innovation systems, clusters, and the knowledge economy. Industrial and corporate change 10(4), pp. 945-974. doi: http://dx.doi.org/10.1093/icc/10.4.945

Denters, B. and Rose, L. E. 2005. Comparing local governance-trends and developments. Taylor and Francis Group Ltd.

Department for Communities and Local Government. (2012). National Planning Policy Framework. [Online] Available at:

https://www.gov.uk/government/uploads/system/uploads/attachment_data/file/6077/2116950.pdf [Accessed: 10 April 2015]

Dunning, J.H. and Narula, R. 1997. Developing countries versus multinationals in a globalising world: the dangers of falling behind. In: Buckley, P. and Ghauri, P. eds. Multinational enterprises and emerging markets: managing increasing interdependence. London: Dryden Press, pp. 467-488.

Evans, B. and O'Brien, M. 2015. Local governance and soft infrastructure for sustainability and resilience. In: Paleo, U.F. ed. Risk Governance. Netherlands: Springer, pp. 77-97. doi: http://dx.doi.org/10.1007/978-94017-9328-5_5

Faguet, J. P. 2014. Decentralization and governance. World Development 53, pp. 2-13. doi: http://dx.doi.org/10.1016/j.worlddev.2013.01.002

Government of Alberta. 2013. Alberta's Social Policy Framework. [Online] Available at: http://socialpolicyframework.alberta.ca/files/documents/ahs-nonannotatedfrmwrk-webfinal.pdf [Accessed: 24 April 2015].

Haque, M. S. 1997. Editorial introduction: local governance in developing nations: re-examining the question of accountability. Regional Development Dialogue 18(2), pp. 1-25.

Harvey, D. 1989. From managerialism to entrepreneurialism: the transformation in urban governance in late capitalism. Geografiska Annaler. Series B, Human Geography 71(1), pp. 3-17. doi: http://dx.doi.org/10.2307/490503

Haus, M. and Sweeting, D. 2006. Mayors, citizens and local democracy. In: Bäck, H. et al. eds. The European Mayor: Political Leaders in the Changing Context of Local Democracy. 10th ed. VS Verlag für Sozialwissenschaften, pp. 151-175. doi: http://dx.doi.org/10.1007/978-3-531-90005-6_7

Heinelt, H. and Hlepas, N. K. 2006). Typologies of local government systems In: Bäck, H. et al. eds. The European Mayor: Political Leaders in the Changing Context of Local Democracy. 10th ed. VS Verlag für Sozialwissenschaften, pp. 21-42. doi: http://dx.doi.org/10.1007/978-3-531-90005-6_2

Hunte, K. 2014. A Case for tracking non-financial aid flows more Effectively. Yale Journal of International Affairs. [Online] Available at: http://yalejournal.org/article_post/a-case-for-tracking-non-financial-aid-flows-moreeffectively/ [Accessed: 17 April 2015]

John, P. 2001. Local governance in Western Europe. London: Sage Publications Ltd.

Krott, M. et al. 2014. Actor-centred power: the driving force in decentralised community based forest governance. Forest Policy and Economics 49, pp. 34-42. doi: http://dx.doi.org/10.1016/j.forpol.2013.04.012

Lee, S. M. et al. 2012. Open innovation in the public sector of leading countries. Management Decision 50(1), pp. 147-162. doi: http://dx.doi.org/10.1108/00251741211194921

Manor J. 1999. The Political Economy of Democratic Decentralisation, The World Bank, Washington doi: http://dx.doi.org/10.1596/0-8213-4470-6

Medium Term Development Strategy 2010-2014 [Online] Available at: http://www.economicaffairs.gov.bb/download.php\%3Fid\%3D85 [Accessed: 24 April 2015].

Ministry for Children and Families. 2000. Youth Policy Framework. [Online] Available at: http://www.mcf.gov.bc.ca/youth/pdf/policy_framework.pdf [Accessed: 24 April 2015].

National Strategic Plan of Barbados 2005-2025 [Online] Available at: http://www.sice.oas.org/ctyindex/BRB/Plan2005-2025.pdf [Accessed: 14 April 2015]. 
Oakerson, R. J. and Parks, R. B. 1989. Local government constitutions: a different view of metropolitan governance. The American Review of Public Administration 19(4), pp. 279-294. doi: http://dx.doi.org/10.1177/027507408901900402

Osborne, D. 1993. Reinventing government. Public Productivity \& Management Review, 16 (4), pp. 349-356. doi: http://dx.doi.org/10.2307/3381012

Porter, M. E. 1998. Clusters and the new economics of competition. Harvard Business Review 76 (6), pp. 77-90.

Reddel, T. and Woolcock, G. 2004. From consultation to participatory governance? A critical review of citizen engagement strategies in Queensland. Australian Journal of Public Administration 63(3), pp. 75-87. doi: http://dx.doi.org/10.1111/j.1467-8500.2004.00392.x

Rhodes, R. A. W. 1996. The new governance: governing without government1. Political studies 44(4), pp. $652-667$. doi: http://dx.doi.org/10.1111/j.1467-9248.1996.tb01747.x

Rosenfeld, S. A. 1997. Bringing business clusters into the mainstream of economic development. European planning studies 5(1), pp. 3-23. doi: http://dx.doi.org/10.1080/09654319708720381

Samila, S., and Sorenson, O. 2011. Venture capital, entrepreneurship, and economic growth. The Review of Economics and Statistics 93(1), pp. 338-349. doi: http://dx.doi.org/10.1162/REST_a_00066

Singh, A. 2001. Foreign Direct Investment and International Agreements: a south perspective. Occasional Papers: Trade-Related Agenda, Development and Equity. Geneva, Switzerland: South Centre.

Stathopoulou, S. et al. 2004. Rural entrepreneurship in Europe: a research framework and agenda. International Journal of Entrepreneurial Behavior \& Research 10(6), pp. 404-425. doi: http://dx.doi.org/10.1108/13552550410564725

Stoker, G. 1998. Governance as theory: five propositions. International Social Science Journal 155 (1), pp. 17-28. doi: http://dx.doi.org/10.1111/1468-2451.00106

Stoker, G. 2011. Was local governance such a good idea? A global comparative perspective. Public Administration 89(1), pp. 15-31. doi: http://dx.doi.org/10.1111/j.1467-9299.2011.01900.x

Thompson, M. A. and Rushing, F. W. 1999. An empirical analysis of the impact of patent protection on economic growth: an extension. Journal of Economic Development 24(1), pp. 67-76.

Thurik, A. R. 2009. Entreprenomics: entrepreneurship, economic growth and policy. In: Acs, Z.J. et al. eds. Entrepreneurship, Growth, and Public Policy. Cambridge: Cambridge University Press, pp. 219-249. doi: http://dx.doi.org/10.1017/CBO9780511805950.011

Treisman, D. 2002. Defining and measuring decentralization: a global perspective. Unpublished manuscript.

Watson, K. 2011. Slavery and economy in Barbados. [Online] Available at: http://www.bbc.co.uk/history/british/empire_seapower/barbados_01.shtml. [Accessed: 17 April 2015].

Wennberg, K. and Lindqvist, G. 2008. How do entrepreneurs in clusters contribute to economic growth?. SSE/EFI Working Paper Series in Business Administration No. 2008:3. 